\title{
GIS IN SOIL SURVEY AND SOIL MAPPING
}

\author{
Perparim AMETID, Besim AJVAZI (iD* \\ Department of Geodesy, Faculty of Civil Engineering, University of Prishtina "Hasan Prishtina", Prishtine, Kosovo
}

Received 14 February 2020; accepted 14 June 2021

\begin{abstract}
The main goal of this paper is to present a methodology for land evaluation by supporting decision-makers with reliable information for the land-use planning process. One of the focuses of this paper is given to the survey process and interpretation between soil survey, soil survey interpretation, and physical land evaluation. Such processes are realized using mobile mapping tools with integrated Global Position Systems (GPS) and Geographic Information Systems (GIS). Both have increased the efficiency of data communication technologies by enabling real-time communication between people located in the field and office as well. For the soil classification as a key component of soil surveys is used World Reference Base (WRB) for Soil Resources. This is a common tool to summarize the wealth of information from soil profiles for the purpose of land evaluation. The final results showed a soil classification map. Such results are derived from many activities, since it includes a preliminary land evaluation, field soil survey with auger holes and profiles as well. This methodology is used for the first time in the selected study area.
\end{abstract}

Keywords: soil survey, Geographic Information System, Global Position System, World Reference Base.

\section{Introduction}

Soil surveys provide the information needed for land use management and land use planning. The selection of good land for farming is as old as agricultural land use. The fact that during the early Holocene, some 8000 years ago the first farmers in Europe were cultivating the relatively rich loss soils and alluvial plains shows that these people were aware of major differences in fertility between major land units and that they were able to judge which soil was more productive than others (Deckers et al., 2004). This is fundamental for any development activity, as land is now becoming an increasingly scarce resource for mankind. This is on one hand because of population growth, which increases the human pressure on the environment, and the other hand to misuse and depletion of renewable resources, which lead to a general decrease in the quality and productivity of the land. These two leading forces interact in producing their effects (Homer-Dixon, 1999), and the consequences of this scarcity for the mankind calls for a sustainable use of natural and human resources and appropriate planning of their exploitation. As a result of human activities such as industrial and others may affect soil degradation and reduction in soil functions. To prevent soil degradation and to rehabilitate the potentials of degraded soils, reliable soil data are the most important prerequisite for the design of appropriate land-use systems and soil management practices as well as for a better understanding of the environment. Planning requires knowing how the land characteristics vary within a certain area, and how this affects the suitability of the territory for a specific land utilization (Food and Agriculture Organization of the United Nations [FAO], 2006).

The suitability of specific land use needs to be evaluated, which may be exemplified by FAO (1983): "The main objective of land evaluation is to put at the disposal of the user, whether farmer, planner, government official or politician, relevant information about land resources that is necessary for planning, development and management decisions". However, Beek et al. (1997) mean that placing land evaluation in the broader context of land use planning reveals "a potential gap between technology-oriented land resource specialists, concerned with the present and future performance of the land, and human-oriented scientists concerned with the land users and their wellbeing".

In general, the object of land evaluation is the land, considered as a whole and not as a simple sum of single environmental components. Therefore, studying and evaluating the land requires considering the complexity of the reality in all its components, which are in turn very complex sub-systems. Since every component is mutually tied

*Corresponding author. E-mail: besim.ajvazi@uni-pr.edu 
to the others, depending on them and influencing them at the same time, it is necessary to adopt a holistic approach, studying the land as the result of all the inter-relationships which occur between geology, geomorphology, soils, climate, vegetation, hydrology, and human activity. The holistic approach allows the identification and subdivision of land in holistic portions, which then can be sampled and described analytically by the traditional disciplines, such as botany, geology, soil science, remote sensing, etc. A land evaluation campaign requires the surveyors to perform many kinds of analysis and observations, trying to "capture" as much as possible of the situation of all the different environmental components in the area. Inevitably, every surveyor has a specific background and will be more proficient in a given discipline. Therefore, the coordination between the different components of a team and mentioned technologies plays a very important role in the success of a survey.

\section{Study area}

For the study area, the Municipality of Rahovec in Kosovo has been selected (Figure 1). This area is located in the south-western part of Kosovo with a total area of $276 \mathrm{~km}^{2}$ and 76577 inhabitants. The territory of this municipality largely has a good geographic position, which covers the central part of the Dukagjini region (the west part of Kosovo). It is positioned between $42^{\circ} 30^{\prime}$ and $42^{\circ} 50^{\prime}$ north latitude and $20^{\circ} 21^{\prime}$ and $20^{\circ} 55^{\prime}$ longitude. Regarding the

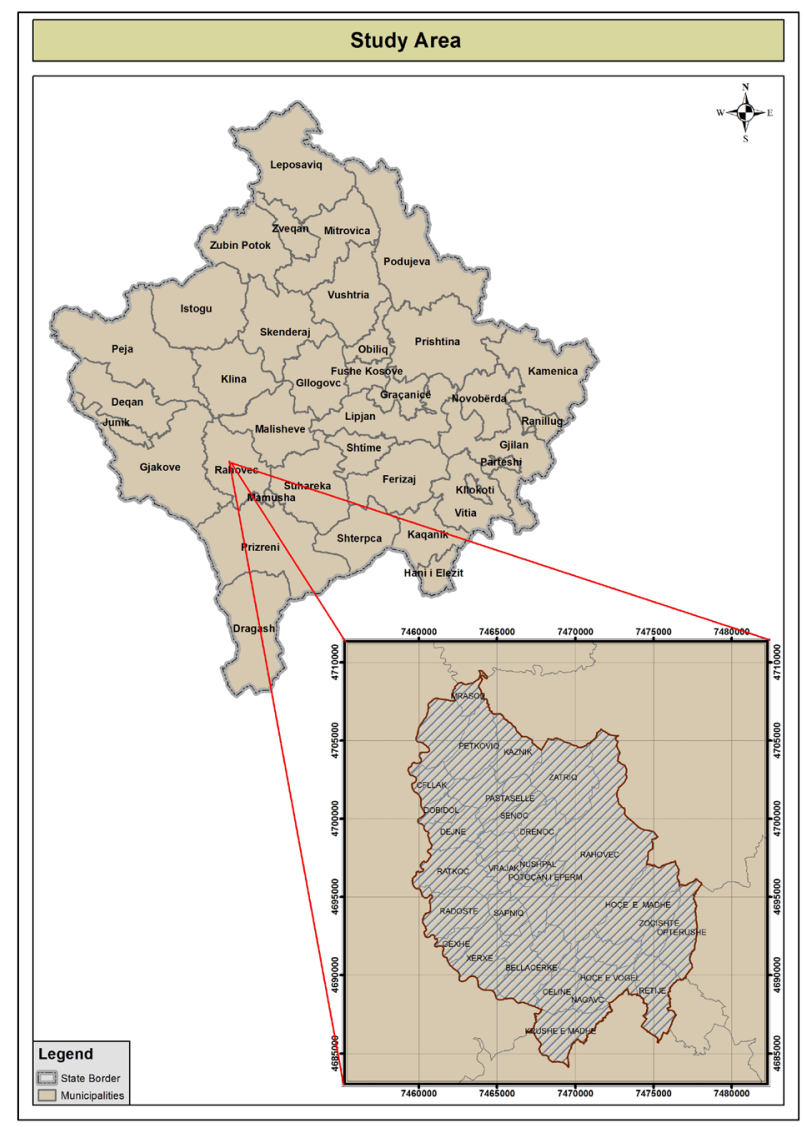

Figure 1. Study area topography, settlements are divided into three categories: valley-plains, hills, and mountains. Most of the area is lying at an altitude that ranges from 350 to $750 \mathrm{~m}$. This municipality has a continental climate with a Mediterranean influence. Considering statistical data regarding climate and soil, this municipality provides a suitable location for agriculture, especially for viticulture and vegetable. The annual rainfalls reach $765 \mathrm{~mm}$ and the average air temperature is $11.8^{\circ} \mathrm{C}$. Around $60 \%$ of the total area is suitable land for agricultural purposes (Ajvazi \& Czimber, 2019).

\section{Data and methodology}

The methodology used in this study is based on the idea to assess natural resources using satellite and/or aerial images semiautomatic interpretation, as well as the fieldwork to validate interpretation by using soil samples and soil profiles. For the fieldwork GIS, mobile devices were used to facilitate the process, especially in finding the exact location and topography presentation. By using GIS mobile technology all results are stored into a geodatabase and finally presented in a soil map with a definition of different soil typology distribution. The land evaluation process needed for further soil analysis is divided into the following steps:

- Preliminary land unit map;

- Soil survey (augers and profiles);

- Laboratory analysis;

- Soil Map Unit and WRB classification.

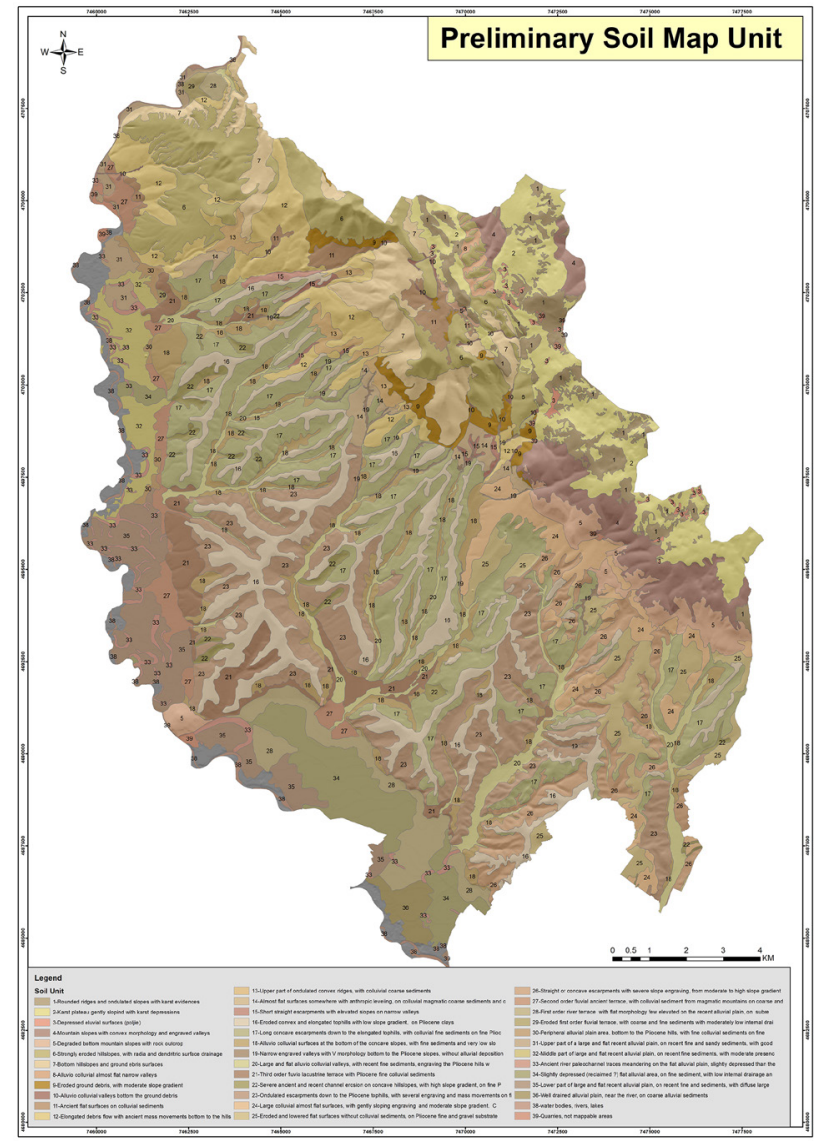

Figure 2. A preliminary land unit map 
Characterization of soil properties is one of the main applications of image interpretation in agriculture. Different land units are distinguished by different land use, morphology, and substrate, whereby polygons with these three homogenous qualities may have the same soil typologies. A preliminary land unit map (Figure 2) and a legend was built through bibliographic material analysis and photo interpretation of RGB aerial images. Photo interpretation results were therefore screen-digitized using GIS software.
A satellite image, using different bands combinations, and elaboration images were used to support the digitalization process.

The following land unit legend represents a short description of each land unit identified in the study area. 38 landscape land units were identified, plus one including artificial areas (Table 1). At this step, we do not have any information about soils, but each land unit, defined with a homogenous parameter may have the same soil typologies.

Table 1. Land unit legend

\begin{tabular}{|c|c|}
\hline $\begin{array}{l}\text { Landform } \\
\text { subsystem }\end{array}$ & Land unit \\
\hline \multirow{3}{*}{$\begin{array}{l}1.1-\text { Karst } \\
\text { plateau and } \\
\text { rounded eroded } \\
\text { mountains on } \\
\text { cretacic limestones } \\
\text { with few surface } \\
\text { drainage }\end{array}$} & $\begin{array}{l}\text { Rounded ridges and undulated slopes with several karst depressions and dominant rock outcrops. Sparse } \\
\text { natural vegetation, shrubs, and rare trees with few pasture traces }\end{array}$ \\
\hline & $\begin{array}{l}\text { Karst plateau, gently sloping, with few surface drainage and diffuse karst depressions (sinkholes). Moderately } \\
\text { dense oak trees forest }\end{array}$ \\
\hline & Depressed eluvial elongated surfaces, almost flat, with shifting cultivations or pasture \\
\hline \multirow{2}{*}{$\begin{array}{l}1.2 \text { - Mountain } \\
\text { slopes with parallel } \\
\text { surface drainage } \\
\text { on cretacic } \\
\text { limestone }\end{array}$} & $\begin{array}{l}\text { Mountain slopes, convex morphology, with engraved straight and narrow valleys. Slope gradient moderately } \\
\text { high. Dominant oak trees forest }\end{array}$ \\
\hline & $\begin{array}{l}\text { Bottom side of mountain slopes, with coarse colluvial calcareous gravels. Moderately steep slope. Frequent } \\
\text { surface coarse fragments and sparse rockiness. Bare soil or sparse shrubs and trees }\end{array}$ \\
\hline \multirow{7}{*}{$\begin{array}{l}1.3 \text { - Eroded } \\
\text { Hillslopes with } \\
\text { radial surface } \\
\text { drainage on } \\
\text { Jurassic magmatic } \\
\text { substrate } \\
\text { (serpentinite } \\
\text { prevalent) }\end{array}$} & $\begin{array}{l}\text { Strongly eroded hillslopes, with several radials and dendritic surface drainage, bare soils with sparse shrubs, } \\
\text { somewhere pastured }\end{array}$ \\
\hline & $\begin{array}{l}\text { Bottom hillslope part and ground debris surfaces, with moderate slope gradient and moderately dense oak } \\
\text { forest }\end{array}$ \\
\hline & Alluvio colluvial almost flat narrow valleys down the eroded hillslopes, covered by dense tree forest \\
\hline & Eroded ground debris, with moderate slope gradient. Bare soils or sparse shrubs \\
\hline & Alluvio colluvial valleys bottom the ground debris, almost flat morphology with shifting cultivations \\
\hline & Ancient flat smoothing surfaces on colluvial sediments with rainfed cultivations \\
\hline & $\begin{array}{l}\text { Elongated debris flows with ancient mass movement bottom to the hills with magmatic substrate and with } \\
\text { colluvial sediments from the upper surfaces. Low slope gradient and covered by oak forest on the top, rainfed } \\
\text { cultivations, and sparse vineyards at the bottom }\end{array}$ \\
\hline \multirow{10}{*}{$\begin{array}{l}2.1 \text { - Hills with } \\
\text { elongated and } \\
\text { rounded ridges } \\
\text { engraved by } \\
\text { dendritic surface } \\
\text { drainage. Pliocene } \\
\text { gravels, sand, and } \\
\text { clay substrate }\end{array}$} & $\begin{array}{l}\text { The upper part of undulated convex ridges, with colluvial magmatic coarse material on Pliocene clay } \\
\text { substrate. Low slope gradient. Diffuse rainfed cultivations and urban settlements }\end{array}$ \\
\hline & $\begin{array}{l}\text { Almost flat surfaces somewhere with anthropic leveling, on colluvial magmatic coarse sediments and clay } \\
\text { Pliocene substrate. Mainly vineyards cultivations }\end{array}$ \\
\hline & Short straight escarpments with elevated slopes on narrow valleys. Not cultivated areas with sparse shrubs \\
\hline & $\begin{array}{l}\text { Eroded convex and elongated top hills with low slope gradient, on Pliocene clays and coarser sediments with } \\
\text { shallow surface colluvial gravel sediments from magmatic hills. Diffuse intensive vineyards }\end{array}$ \\
\hline & $\begin{array}{l}\text { Long concave escarpments down to the elongated top hills, with colluvial fine sediments on fine Pliocene } \\
\text { sediments. Moderate slope gradient, somewhere with mass movements, diffuse rainfed cultivations, and, } \\
\text { somewhere, intensive vineyards }\end{array}$ \\
\hline & $\begin{array}{l}\text { Alluvio colluvial surfaces at the bottom of the concave slopes, with fine sediments and a very low slope } \\
\text { gradient. Dominant intensive vineyards and rainfed cultivations }\end{array}$ \\
\hline & $\begin{array}{l}\text { Narrow engraved valleys with V morphology bottom to the Pliocene slopes, without alluvial depositions and } \\
\text { covered by natural vegetation }\end{array}$ \\
\hline & $\begin{array}{l}\text { Large and flat alluvio colluvial valleys, with recent fine sediments, engraving the Pliocene hills with very low } \\
\text { slope gradient. Rainfed cultivations }\end{array}$ \\
\hline & Third order fluvio-lacustrine terrace with Pliocene fine colluvial sediments \\
\hline & $\begin{array}{l}\text { Severe ancient and recent channel erosion on concave hillslopes, with high slope gradient, on fine Pliocene } \\
\text { sediments. Not cultivated or with shifting cultivations }\end{array}$ \\
\hline
\end{tabular}


End of Table 1

\begin{tabular}{|c|c|}
\hline $\begin{array}{l}\text { Landform } \\
\text { subsystem }\end{array}$ & Land unit \\
\hline \multirow{4}{*}{$\begin{array}{l}2.2 \text { - Hills with } \\
\text { long hillslopes on } \\
\text { Pliocene substrate } \\
\text { with colluvial } \\
\text { and eluvial "terra } \\
\text { rossa" sediments } \\
\text { from calcareous } \\
\text { mountains }\end{array}$} & $\begin{array}{l}\text { Undulated escarpments down to the Pliocene top hills, with several engraving and mass movements on fine } \\
\text { Pliocene sediments. Rainfed cultivations mixed to oak forests }\end{array}$ \\
\hline & $\begin{array}{l}\text { Large colluvial almost flat surfaces, with gently sloping engraving and moderate slope gradient. Colluvial and } \\
\text { eluvial "terra rossa" sediments on Pliocene fine and gravel substrate }\end{array}$ \\
\hline & $\begin{array}{l}\text { Eroded and lowered flat surfaces without colluvial sediments, on Pliocene fine and gravel substrate. Diffuse } \\
\text { intensive vineyards and rainfed cultivations }\end{array}$ \\
\hline & $\begin{array}{l}\text { Straight or concave escarpments with severe slope engraving, from moderate to high slope gradient, mainly } \\
\text { oak forest or sparse rainfed cultivation, somewhere urbanized }\end{array}$ \\
\hline \multirow{2}{*}{$\begin{array}{l}3.1 \text { - River terraces } \\
\text { on subrecent } \\
\text { alluvial sediments }\end{array}$} & $\begin{array}{l}\text { Second-order fluvial ancient terrace, with colluvial sediment from magmatic mountains on course and sandy } \\
\text { fluvial sediments. Rainfed crops and urban settlements }\end{array}$ \\
\hline & $\begin{array}{l}\text { First-order river terrace with flat morphology few elevated on the recent alluvial plain, on sub recent fine and } \\
\text { sandy fluvial sediments. Diffuse rainfed crops and forages }\end{array}$ \\
\hline \multirow{11}{*}{$\begin{array}{l}3.2 \text { - Flat alluvial } \\
\text { plain on recent } \\
\text { fluvial sediments }\end{array}$} & $\begin{array}{l}\text { Eroded first order fluvial terrace, with coarse and fine sediments with moderately low internal drainage. } \\
\text { Forage crops, pasture or forest }\end{array}$ \\
\hline & $\begin{array}{l}\text { Peripheral alluvial plain area, bottom to the Pliocene hills, with fine colluvial sediments on fine alluvial } \\
\text { sediments and moderately low internal drainage. Rainfed crops }\end{array}$ \\
\hline & $\begin{array}{l}\text { The upper part of a large and flat recent alluvial plain, on recent fine and sandy sediments, with good internal } \\
\text { drainage. Irrigated and rainfed crops }\end{array}$ \\
\hline & $\begin{array}{l}\text { The middle part of large and flat recent alluvial plain, on recent fine sediments, with the moderate presence } \\
\text { of paleochannel traces and moderately good internal drainage. Irrigated and rainfed crops }\end{array}$ \\
\hline & $\begin{array}{l}\text { Ancient river paleochannel traces meandering on the flat alluvial plain, slightly depressed than the alluvial } \\
\text { plain, on coarse fluvial sediments and good internal drainage. Irrigated and rainfed crops }\end{array}$ \\
\hline & $\begin{array}{l}\text { Slightly depressed (reclaimed?) flat alluvial area, on fine sediment, with low internal drainage, and with } \\
\text { irrigation channels. Dominant Irrigated crops }\end{array}$ \\
\hline & $\begin{array}{l}\text { The lower part of large and flat recent alluvial plain, on recent fine and sediments, with diffuse large } \\
\text { meandering paleochannel traces and moderate internal drainage. Irrigated and rainfed crops }\end{array}$ \\
\hline & Well-drained alluvial plain, near the river, on coarse alluvial sediments, and with rainfed crops \\
\hline & $\begin{array}{l}\text { Flooding area near the actual riverbed, on course and gravel sediments. Natural vegetation and often diffuse } \\
\text { quarries for sand and gravels }\end{array}$ \\
\hline & Water bodies, rivers, lakes, and riparian areas \\
\hline & Quarries, not mappable areas \\
\hline
\end{tabular}

\subsection{Soil survey}

After the land unit map, an auger holes fieldwork was done to define the distribution of different soil qualities. Augers don't offer complete soil information but give some parameters to define the soil typology boundaries. 2138 Augers holes were performed in all the study area (Figure 4), completely sampled, and analyzed for routine analysis. After auger hole fieldworks profile fieldwork are planned, considering to make at least two profiles per land unit, a total of 71 profiles were done in the area (Figure 3), described, sampled, and analyzed for routine and extra routine analysis.

All the augers and profiles are classified with a taxonomic soil classification system (United States Department of Agriculture [USDA], 2012). Soil profiles are characterized by a vertical succession of horizons and serve as a base for most soil classifications. Some of these give priority to the diagnostic horizon concept, according to which even just one horizon can be enough to characterize a taxonomic unit (USDA, 2012). Other methods, on the contrary, take into consideration the whole soil profile.
The main difficulty is how to group taxonomic units into a hierarchical system inheritable by all classifications as classes, subclasses, groups, subgroups, etc. Thus, it is necessary to set up criteria for classification and to sort classes in priority order.

In such a situation, the setting of the World Reference Base (WRB) for soil resources was established as an internationally accepted system using the FAO's Revised Legend as a framework (FAO, 1998). Soils are grouped into a higher-level on a geographical basis more than taxonomic ones and reflect the soil-landscape associations. The WRB represents a scientific tool to serve different applications in several fields such as agriculture and ecology. It takes into account the morphological characterization rather than the analytical one (USDA, 2012). The general principle of the WRB classification system is the diagnostic horizons, which are identifiable in the field. Then, their characterization must be done considering the soil processes formation. Even the climatic parameters do not need to be taken into account for the soil definition, they should be used for interpretation only. The WRB is made up of 30 reference soil groups and the classes are differentiated according to 


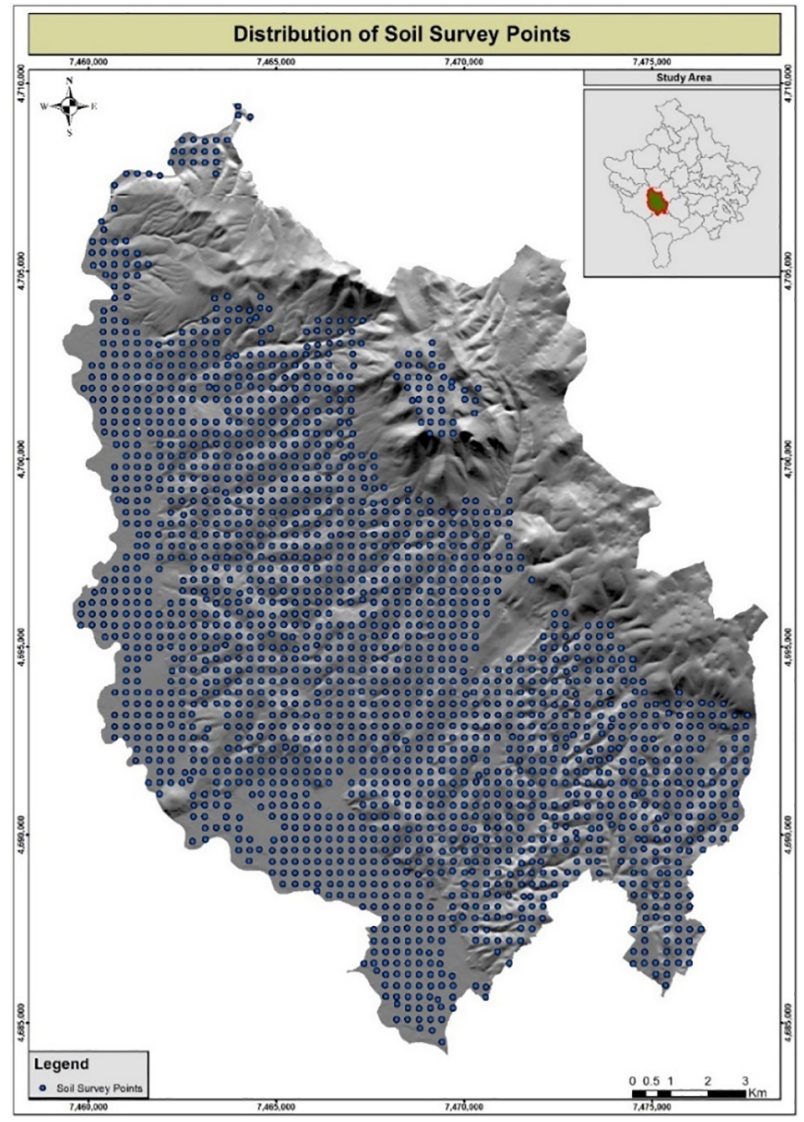

Figure 3. Augers holes distribution in the study area

the primary pedogenetic process responsible for soil characteristics and properties unless the original material is predominant for the pedogenetic process. For each soil group reference, a list of possible soil sub-units was set in priority order to reflect any secondary pedogenetic process which affects significantly the primary properties of the soil. All the augers and profiles are implemented in a geodatabase for further suitability elaborations.

\subsection{GIS mobile application}

Soil data is spatial and can be easily handled and analyzed using GIS. Data analysis of different formats to get the desired information as well as sharing and dissemination of information is easier by utilizing GIS techniques (Ramakrishnan \& Guruswamy, 2009). Mobile GIS is an integrated technological framework for the access of geospatial data and location-based services through mobile devices, such as Pocket PCs, Personal Digital Assistants (PDA), or smart cellular phones. With the advancement and convergence of GPS, Internet, and wireless communication technologies, mobile GIS has a great potential to play an important role in field data acquisition and validation (Tsou, 2004). The field data collection process was completed using a GIS mobile application. Initially, it is developed a GIS mobile application based on the characteristics of each attribute that was necessary to be collected. All the field data including the pictures are

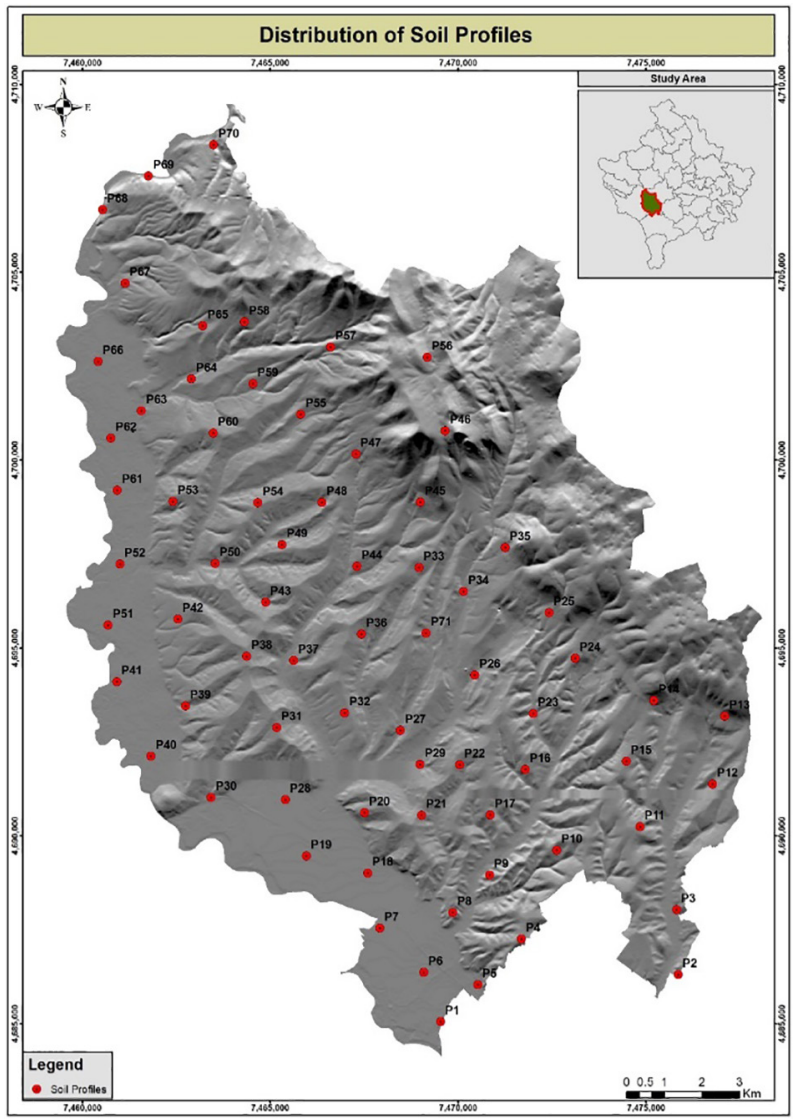

Figure 4. Profiles distribution in the study area

integrated into a specific geodatabase. Such geodatabase is synchronized in real-time through GPRS. The field mobile application was used to:

- Collect accurate and reliable data in the field;

- Integrate GPS and digital cameras during data collection in the field;

- Improves productivity and data populating in GIS.

GPS is another important part of mobile devices. The way GPS is used to provide GIS data can be categorized into two broad areas. The first is simply applying a controlling reference to some other source of data from which the GIS can collect the information that it needs. The other is to use GPS to acquire the GIS information directly (French, 1996). GPS technology provides the fastest, easiest, and most productive method of mapping the locations and geometries of ground features for a GIS database (Trimble, 2007). The entry of attribute information into a GIS by using a GPS receiver is facilitated by a data dictionary, which is a hierarchical collection of textual terms stored in the GPS receiver's memory. It helps to determine the location on earth with a few meters' accuracy. Since a grid with $300 \times 300 \mathrm{~m}$ is set for the field survey, GPS helps in navigating the location of a specific survey point.

The overall process of the GIS/GPS mobile application should be followed by the steps as shown below:

1) Geodatabase design for data collection;

2) Application development (forms and programming). 


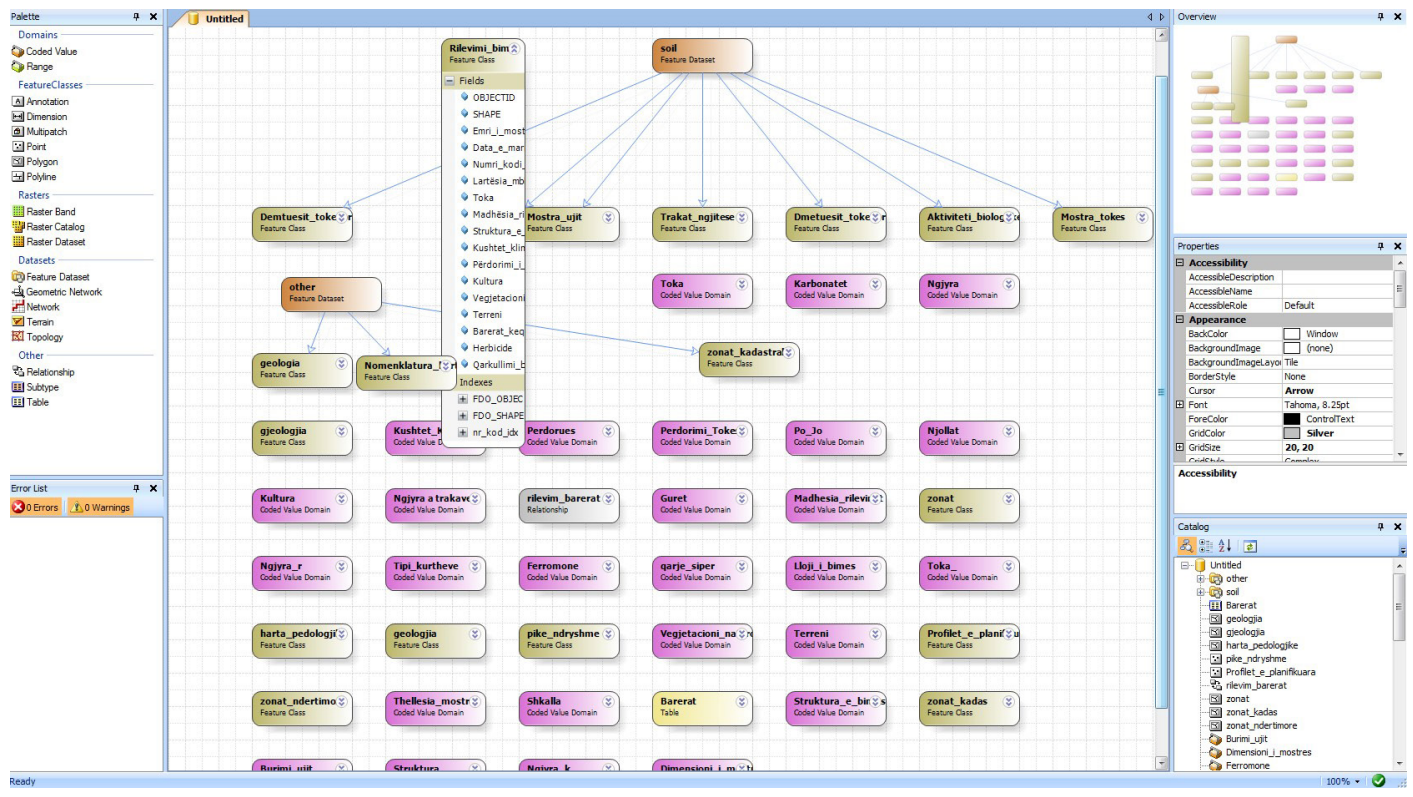

Figure 5. Geodatabase design

The geodatabase design was conducted based on a set of common steps with basic GIS designs. All geodatabase design has involved organizing spatial information into a series of data based on layers and other information related to this spatial data. So, before we did the geodatabase design, initially based on the project requirements we identified the features to be used, in relation to the characteristics of the samples to be taken in the field.

The two main steps which are important to be followed within a process of geodatabase design are identification of the features and defining the structure of tables and attributes which includes as well the field, field type, the code list, table relationships, subtypes, etc. The geodatabase schema is presented in Figure 5.

The GIS mobile application is developed to manage the fieldwork of the data collection (Figure 6). By collecting the data in the fields, they will be saved synchronously in a geodatabase. The next figure shows parts of the application.

The development of forms is done with XML and VB script as well as for data relations. Also, the data is saved locally in the memory of the device in. axf format and shapefile for spatial data, as well as in DBF for textual data types. The application also enables the device to be configured with the GPS receiver. When exporting data, layers are defined that can be created, changed, deleted and layers that serve for orientation and identification as well as export of raster formats (orthophotos, municipal border, cadastral zone border, etc.).

Using the device camera, the pictures could be taken and saved at a certain feature in a geodatabase. In cases where a point is not accessible, it could be moved to a certain location (Figure 7). This is due to GPS signals received by the mobile device.

\section{Results and discussions}

To build the final land unit map and legend describing all the different land units obtained, several parameters were taken into account: land use, dominant lithology, landform, land use, land cover, vegetation, and soil (Table 2).

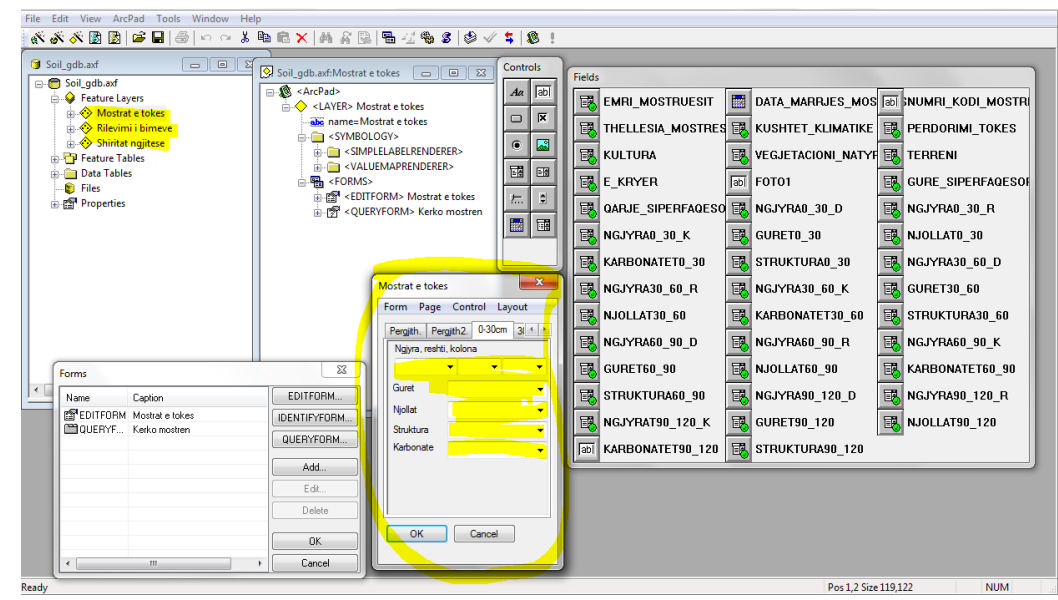

Figure 6. The GIS mobile application 

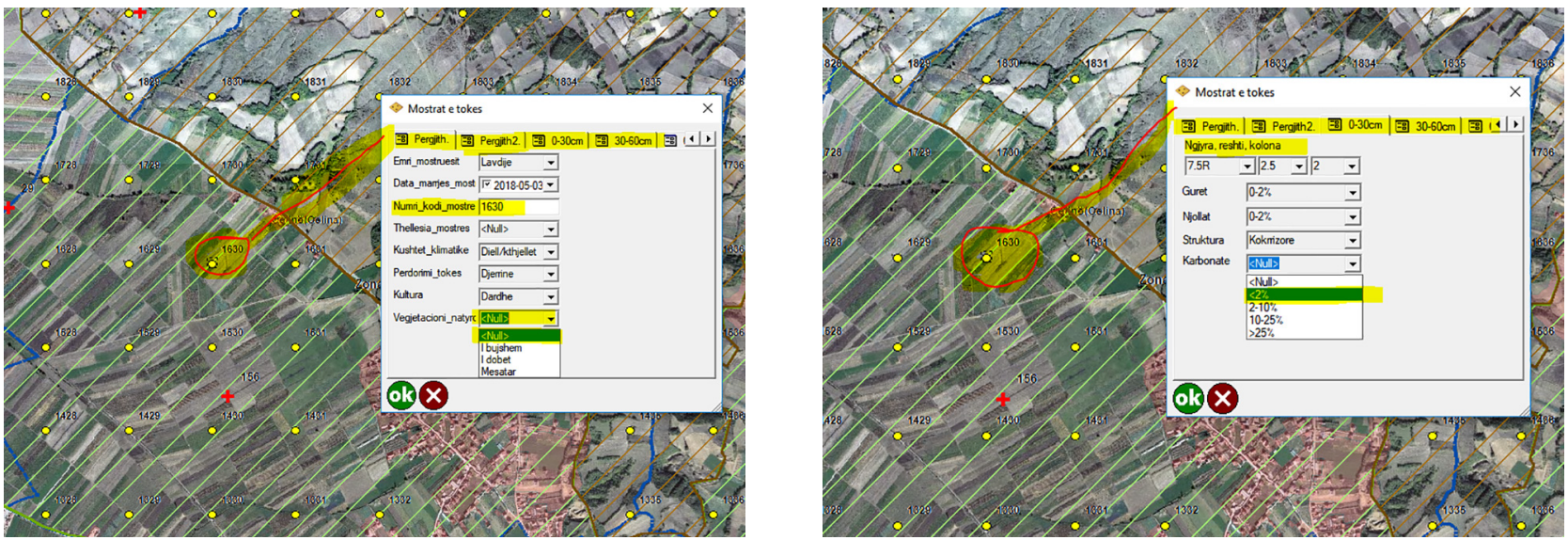

Figure 7. Data registration

Table 2. The soil qualities parameters considered to describe the Soil Units are showing in the following tables

\begin{tabular}{|c|c|c|}
\hline $\begin{array}{c}\text { Soil Quality } \\
\text { Parameter }\end{array}$ & Classes & Values \\
\hline \multirow{4}{*}{ Soil depth } & Very shallow & $<25 \mathrm{~cm}$ \\
\hline & Shallow & $25-50 \mathrm{~cm}$ \\
\hline & Moderately deep & $50-100 \mathrm{~cm}$ \\
\hline & Deep & $>100 \mathrm{~cm}$ \\
\hline \multirow{5}{*}{$\begin{array}{l}\text { Soil rooting } \\
\text { depth }\end{array}$} & Very shallow & $<25 \mathrm{~cm}$ \\
\hline & Shallow & $25-50 \mathrm{~cm}$ \\
\hline & Moderately deep & $50-100 \mathrm{~cm}$ \\
\hline & Deep & $100-150 \mathrm{~cm}$ \\
\hline & Very deep & $>150 \mathrm{~cm}$ \\
\hline \multirow{5}{*}{$\begin{array}{l}\text { Available } \\
\text { water capacity } \\
\text { (AWC) }\end{array}$} & Very low & $0-50 \mathrm{~mm}$ \\
\hline & Low & $50-100 \mathrm{~mm}$ \\
\hline & Moderate & $100-150 \mathrm{~mm}$ \\
\hline & High & $150-200 \mathrm{~mm}$ \\
\hline & Very high & $>200 \mathrm{~mm}$ \\
\hline \multirow{6}{*}{$\begin{array}{l}\text { Permeability } \\
\text { (Ksat) }\end{array}$} & Very high & $>100 \mathrm{~mm} / \mathrm{s}$ \\
\hline & High & $10-100 \mathrm{~mm} / \mathrm{s}$ \\
\hline & Moderately high & $1-10 \mathrm{~mm} / \mathrm{s}$ \\
\hline & Moderately low & $0.1-1 \mathrm{~mm} / \mathrm{s}$ \\
\hline & Low & $0.01-0,1 \mathrm{~mm} / \mathrm{s}$ \\
\hline & Very low & $<0.01 \mathrm{~mm} / \mathrm{s}$ \\
\hline \multirow{4}{*}{$\begin{array}{l}\text { Cation } \\
\text { Exchange } \\
\text { capacity (CEC) }\end{array}$} & Very low & $<5 \mathrm{cmol} / \mathrm{Kg}$ soil \\
\hline & Low & $5-10 \mathrm{cmol} / \mathrm{Kg}$ soil \\
\hline & medium & $10-20 \mathrm{cmol} / \mathrm{Kg}$ soil \\
\hline & High & $>20 \mathrm{cmol} / \mathrm{Kg}$ soil \\
\hline \multirow{6}{*}{$\begin{array}{l}\text { Coarse } \\
\text { fragments }\end{array}$} & None & $<1 \%$ \\
\hline & weak & $1-5 \%$ \\
\hline & Common & $5-15 \%$ \\
\hline & Many & $15-35 \%$ \\
\hline & Abundant & $35-60 \%$ \\
\hline & Very abundant & $>60 \%$ \\
\hline
\end{tabular}

\begin{tabular}{|c|c|c|}
\hline $\begin{array}{l}\text { Soil Quality } \\
\text { Parameter }\end{array}$ & Classes & Values \\
\hline \multirow{6}{*}{$\begin{array}{l}\text { Calcium } \\
\text { carbonate }\end{array}$} & Not calcareous & $<0.5 \%$ \\
\hline & $\begin{array}{l}\text { Very weakly } \\
\text { calcareous }\end{array}$ & $0.5-1 \%$ \\
\hline & $\begin{array}{l}\text { Weakly } \\
\text { calcareous }\end{array}$ & $1-5 \%$ \\
\hline & \begin{tabular}{|l|}
$\begin{array}{l}\text { Moderately } \\
\text { calcareous }\end{array}$ \\
\end{tabular} & $5-10 \%$ \\
\hline & Calcareous & $10-20 \%$ \\
\hline & Very calcareous & $>20 \%$ \\
\hline \multirow{7}{*}{ Stoniness } & None & $0 \%$ \\
\hline & Weak & $0-0.1 \%$ \\
\hline & Moderate & $0.1-3 \%$ \\
\hline & Common & $3-15 \%$ \\
\hline & Many & $15-50 \%$ \\
\hline & High & $50-90 \%$ \\
\hline & Very high & $>90 \%$ \\
\hline \multirow{6}{*}{ Rockiness } & None & $0 \%$ \\
\hline & Weakly stony & $0-2 \%$ \\
\hline & Stony & $2-10 \%$ \\
\hline & Very stony & $10-25 \%$ \\
\hline & Extremely stony & $25-50 \%$ \\
\hline & Rock outcrop & $>90 \%$ \\
\hline \multirow{4}{*}{$\begin{array}{l}\text { Exchangeable } \\
\text { cations } \\
\text { saturation }\end{array}$} & Very low & $<35 \%$ \\
\hline & Low & $35-50 \%$ \\
\hline & Medium & $50-75 \%$ \\
\hline & High & $>75 \%$ \\
\hline \multirow{6}{*}{ Reaction $(\mathrm{pH})$} & Ultraacid & $<3.5$ \\
\hline & Extremely acid & $3.5-4.4$ \\
\hline & Very highly acid & $5.1-5.5$ \\
\hline & Highly acid & $5.1-5.5$ \\
\hline & Moderately acid & $5.6-6.0$ \\
\hline & Weakly acid & $6.1-6.5$ \\
\hline
\end{tabular}


End of Table 2

\begin{tabular}{|c|l|c|}
\hline $\begin{array}{c}\text { Soil Quality } \\
\text { Parameter }\end{array}$ & \multicolumn{1}{|c|}{ Classes } & \multicolumn{1}{c|}{ Values } \\
\hline \multirow{5}{*}{} & neutral & $6.6-7.3$ \\
\cline { 2 - 3 } & Weakly alcaline & $7.4-7.8$ \\
\cline { 2 - 3 } & $\begin{array}{l}\text { Moderately } \\
\text { alcaline }\end{array}$ & $7.9-8.4$ \\
\cline { 2 - 3 } Texture & Highly alcaline & $8.5-9.0$ \\
\cline { 2 - 3 } & $\begin{array}{l}\text { Very highly } \\
\text { alcaline }\end{array}$ & $>9.0$ \\
\hline \multirow{5}{*}{} & Coarse & sandy; sandy loam \\
\cline { 2 - 3 } & $\begin{array}{l}\text { Moderately } \\
\text { coarse }\end{array}$ & Loamy sand \\
\cline { 2 - 3 } & Medium & Loamy; Silty loam, Silty \\
\cline { 2 - 3 } & Moderately fine & $\begin{array}{l}\text { Sandy clay loam; Clay } \\
\text { loam, Silty clay loam }\end{array}$ \\
\cline { 2 - 3 } & Fine & $\begin{array}{l}\text { Clay, Sandy clay, Silty } \\
\text { clay }\end{array}$ \\
\hline
\end{tabular}

The information derived from the existing data included the observation of the dominant lithology, morphology inside each land unit using DEM 20×20 pixel resolution. The parameters to describe the morphometric characteristics of the land unit components were collected following the modified McDonald's et al. (1998) methodology.

The final step was to define the soil distribution according to the preliminary land unit map and the soil

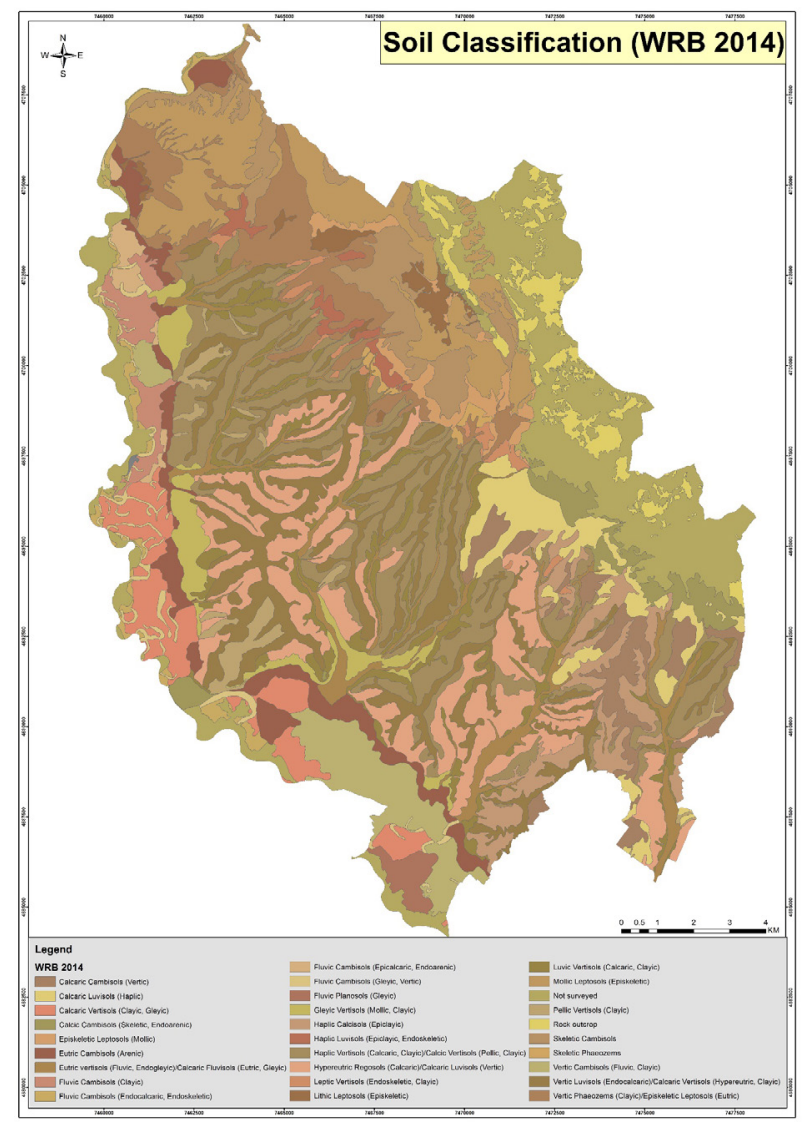

Figure 8. Final soil classification map based on WRB 2014 survey results. The final soil map unit contains many modifications comparing to the preliminary land unit map and consists of 32 soil units and 2 nonsoil units, such as water bodies, artificial areas. The legend consists of the description of landscape parameters at different detail levels: system, subsystem, and land unit; number of the soil unit and the representative soil profile, soil qualities description, and the WRB 2014 soil classification, as soil group with one principal qualifier.

According to the final results (Table 3, Figure 8, Figure 9), around $14 \%$ of the total area is classified as Haplic Vertisols / Calcaric, Clayic; 10\% as Hypereutric Regosols / Calcaric and the other 10\% is Vertic Luvisols / Endocalcaric. These are the three biggest areas of soil distribution.

Table 3. The results of the soil classification

\begin{tabular}{|c|c|c|}
\hline No. & WRB_2014 & $\begin{array}{l}\text { Area } \\
\text { [ha] }\end{array}$ \\
\hline 1 & Calcaric Cambisols (Vertic) & 775 \\
\hline 2 & Calcaric Luvisols (Haplic) & 875 \\
\hline 3 & Calcaric Vertisols (Clayic, Gleyic) & 889 \\
\hline 4 & Calcic Cambisols (Skeletic, Endoarenic) & 528 \\
\hline 5 & Episkeletic Leptosols (Mollic) & 328 \\
\hline 6 & Eutric Cambisols (Arenic) & 889 \\
\hline 7 & Eutric vertisols (Fluvic, Endogleyic) & 935 \\
\hline 8 & Fluvic Cambisols (Clayic) & 343 \\
\hline 9 & Fluvic Cambisols (Endocalcaric, Endoskeletic) & 251 \\
\hline 10 & Fluvic Cambisols (Epicalcaric, Endoarenic) & 162 \\
\hline 11 & Fluvic Cambisols (Gleyic, Vertic) & 249 \\
\hline 12 & Fluvic Planosols (Gleyic) & 172 \\
\hline 13 & Gleyic Vertisols (Mollic, Clayic) & 615 \\
\hline 14 & Haplic Calcisols (Epiclayic) & 917 \\
\hline 15 & Haplic Luvisols (Epiclayic, Endoskeletic) & 212 \\
\hline 16 & Haplic Vertisols (Calcaric, Clayic) & 3390 \\
\hline 17 & Hypereutric Regosols (Calcaric) & 2497 \\
\hline 18 & Leptic Vertisols (Endoskeletic, Clayic) & 175 \\
\hline 19 & Lithic Leptosols (Episkeletic) & 263 \\
\hline 20 & Luvic Vertisols (Calcaric, Clayic) & 1243 \\
\hline 21 & Mollic Leptosols (Episkeletic) & 1800 \\
\hline 22 & Not surveyed & 324 \\
\hline 23 & Pellic Vertisols (Clayic) & 339 \\
\hline 24 & Rock outcrop & 713 \\
\hline 25 & Skeletic Cambisols & 1052 \\
\hline 26 & Skeletic Phaeozems & 73 \\
\hline 27 & Vertic Cambisols (Fluvic, Clayic) & 889 \\
\hline 28 & Vertic Luvisols (Endocalcaric) & 2362 \\
\hline 29 & Vertic Phaeozems (Clayic) & 1397 \\
\hline
\end{tabular}

\section{Conclusions}

The study showed that the development of interactive databases and maps of the soil for this study area is very 


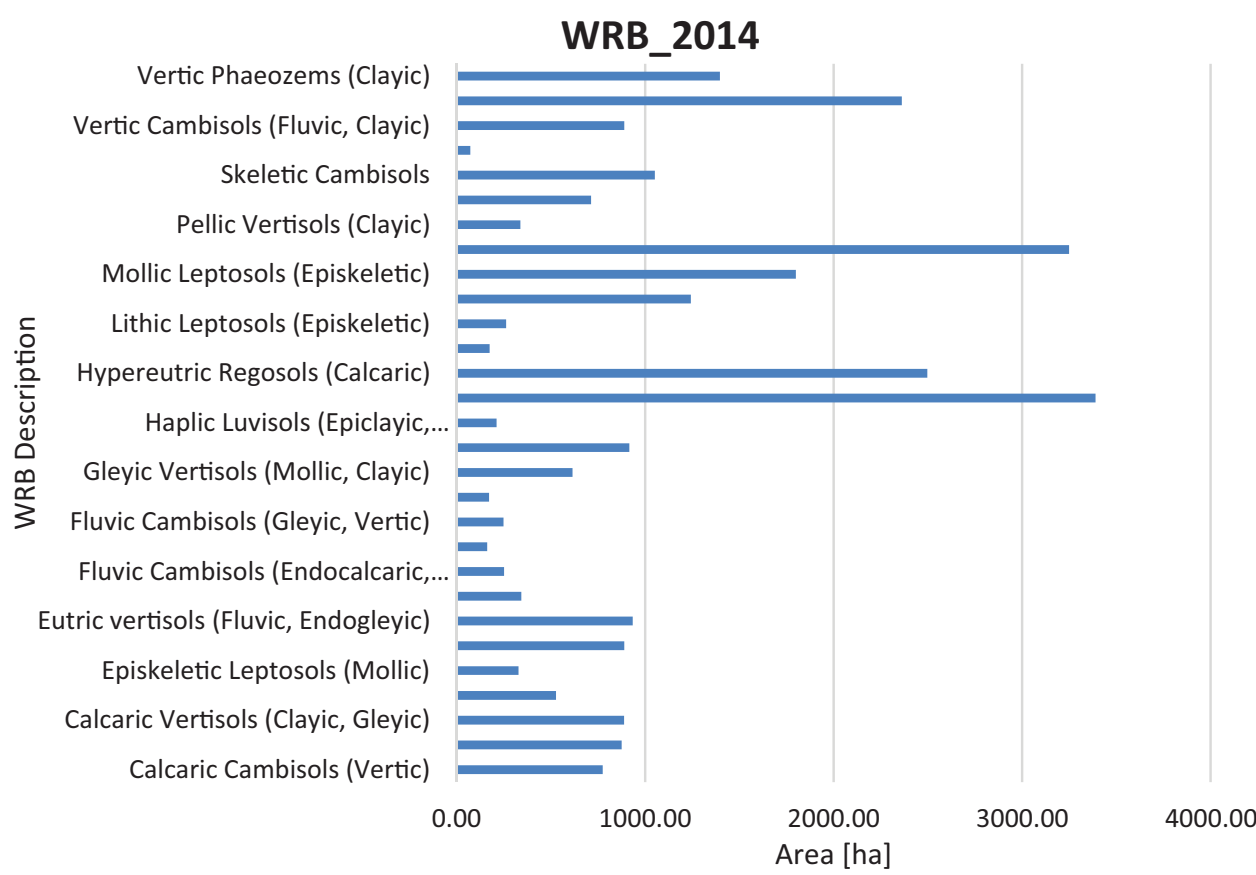

Figure 9. The areas of soil classification

accurate. Also, the study showed the significance of GIS functions while doing soil mapping works. The use of a GIS mobile application enables accurate positioning in the field and consequently increases the accuracy of the soil map. Also, the geodatabase synchronization between mobile and desktop devices enhances the efficiency in the process of field data collection and office data processing.

There was varying absorption of distinctly different taxonomic units into one mapping unit. The use of a combination of auger hole and profiling increases a reliability assessment of the accuracy of soil maps. The final results with the distribution of soil classification will enable proper management of the agricultural land. According to this classification, further, a suitable agricultural map could be developed. From the perspective of land management, the soil classification map could have a great impact in achieving numerous objectives, such as agricultural land taxation, protect the agricultural land areas from degradation, facilitating the land consolidation process, etc. By reaching such objectives, it will enable sustainable agriculture development in the country.

\section{References}

Ajvazi, B., \& Czimber, K. (2019). A comparative analysis of different DEM interpolation methods in GIS: case study of Rahovec, Kosovo. Geodesy and Cartography, 45(1), 43-48. https://doi.org/10.3846/gac.2019.7921

Beek, K. J., de Bie, K., \& Driessen, P. (1997). Land information and land evaluation for land use planning and sustainable land management. Journal of the International Land Use Society, 1, 27-44. https://www.semanticscholar.org/paper/Landinformation-and-land-evaluation-for-land-use-Beek-Bie/49f5 4386ee91c85483776e7e5db685425069f9f9
Deckers, J., \& Spaargaren, O., \& Dondeyne, S. (2004). Soil survey as a basis for land evaluation. Encyclopedia of life support systems. EOLSS Publishers.

Food and Agriculture Organization of the United Nations. (1983). Guidelines: Land evaluation for rainfed agriculture (Soils Bulletin, 52). FAO, Rome, Italy.

Food and Agriculture Organization of the United Nations. (2006). Guidelines for soil description ( $4^{\text {th }}$ ed.). FAO, Rome, Italy. http://www.fao.org/3/a0541e/a0541e.pdf

Food and Agriculture Organization of the United Nations. (1998). World reference base for soil resources. ISSS-ISRICFAO (World Soil Resources Report No. 84). Rome. http://www.fao.org/3/w8594e/w8594e00.htm

French, G. T. (1996). Understanding the g.p.s.: An introduction to the global positioning system. What it is and how it works. Geo Research, Inc., Bethesda. https://www.academia.edu/6847387/ Understanding_the_GPS_An_Introduction_to_the_Global_ Positioning_System_What_It_Is_and_How_It_Works

Homer-Dixon, T. (1999). Environment, scarcity, and violence. Princeton University Press. https://www.jstor.org/stable/j.ctt7pgg0

McDonald, R. C., Isbell, R. F., Speight J. G., Walker, J., \& Hopkins, M. S. (1998). Australian soil and land survey field handbook. CSIRO. https://trove.nla.gov.au/work/8661363

Ramakrishnan, S. S., \& Guruswamy, V. (2009). GIS applications in soil data analysis. Geospatial World. https://www.geospatialworld.net/editorial-board-2/

Trimble. (2007). GPS the first global navigation satellite system ( $1^{\text {st }}$ ed.). Trimble Navigation Limited. https://www.amazon. com/First-Global-Navigation-Satellite-System/dp/B001Q9TYWO

Tsou, M. H. (2004). Integrated Mobile GIS and Wireless Internet Map Servers for Environmental Monitoring and Management. Cartography and Geographic Information Science, 31(3), 153-165. https://doi.org/10.1559/1523040042246052

United States Department of Agriculture. (2012). Key to soil taxonomy. Soil Survey Staff (12\1 $1^{\text {th }}$ ed.). Pocahontas Press. 